\title{
Pemanfaatan Histogram Equalization pada Local Tri Directional Pattern untuk Sistem Temu Kembali Citra
}

\section{Pemanfaatan Histogram Equalization pada Local Tri Directional Pattern untuk Sistem Temu Kembali Citra}

\author{
Nursuci Putri Husain ${ }^{1}$, Nurseno Bayu Aji ${ }^{2}$ \\ ${ }^{1}$ Teknik Informatika, Teknik Informatika, Universitas Islam Makassar, Indonesia. \\ Email: nursuciputrihusain.dty@uim-makassar.ac.id \\ ${ }^{2}$ Teknik Informatika, Fakultas Teknik Elektro, Politeknik Negeri Semarang \\ Email: bayu.nurseno@gmail.com
}

\begin{abstract}
Local tri-directional pattern (LtriDP) is a method of extracting local intensity features from each pixel based on direction. However, this method has not been able to provide good performance in extracting features for image retrieval. One reason that makes image retrieval performance worse is the effect of lighting. Lighting can cause large variations between images. This study proposed utilization of Histogram Equalization (HE). Histogram equalization is a functional method of stretching gray degrees and expanding image contrast. This will make variations in the gray level of the original image can be controlled. There are several main stages in this study, firstly query image and image dataset will be preprocessed with histogram equalization. After that, the image is extracted by a tri-directional pattern and magnitude pattern are searched. A tri-directional pattern will produce two histograms, while a magnitude pattern produces one histogram. The three histograms are combined or joint histogram is performed. Histogram that has been joint is a feature vector. The feature vector will be calculated using a similarity measurement Canberra. After that, an image similar to the query image will be obtained. The experiment was conducted using 3 face datasets namely ORL, BERN, and YALE. The average recall value was 0.422 for the ORL dataset, 0.589 for the BERN dataset, and 0.63 for the YALE dataset. The evaluation show, the proposed method can be used as a process of improving the quality of image datasets in the image retrieval system.
\end{abstract}

Keywords: Image retrieval system, Local tri-directional pattern, Streching Image, Histogram Equalization, Similarity Measurement Canberra.

\begin{abstract}
Abstrak
Local tri-directional pattern (LtriDP) merupakan salah satu metode ekstraksi fitur intensitas lokal dari setiap piksel berdasarkan arah. Namun, metode ini belum mampu memberikan performa yang baik dalam mengekstrak fitur untuk temu kembali citra. Salah satu alasan yang membuat performa temu kembali citra tidak baik adalah pengaruh pencahayaan. Pencahayaan dapat menyebabkan variasi besar antar citra. Penelitian ini mengusulkan pemanfaatan Histogram Equalization (HE). HE merupakan metode fungsional dalam peregangan derajat keabuan dan memperluas kontras citra. Hal ini akan membuat variasi level keabuan dari citra asli dapat terkendali. Ada beberapa tahapan utama dalam penelitian ini, yang pertama citra query dan citra dataset akan terlebih dahulu di preprocessing dengan histogram equalization. Setelah itu, citra tersebut diekstrak fiturnya, dicari pola tri-directional dan pola magnitude. Pola tri-directional akan menghasilkan dua histogram, sedangkan pola magnitude menghasilkan satu histogram. Ketiga histogram tersebut kemudian disatukan atau dilakukan joint histogram. Histogram yang telah dijoint merupakan vektor fitur. Vektor fitur tersebut akan dihitung rankingnya menggunakan pengukuran jarak canberra. Setelah itu, akan didapatkan citra yang mirip dengan citra query. Uji coba dilakukan dengan menggunakan 3 dataset wajah yaitu ORL, BERN, dan YALE. Nilai rata-rata recall yang di dapatkan 0,422 untuk dataset ORL, 0,589 untuk dataset BERN, dan 0,63 untuk dataset YALE. Dari hasil evaluasi tersebut, dapat disimpulkan metode yang diusulkan dapat digunakan sebagai proses peningkatan kualitas dataset citra pada system teти kembali citra.
\end{abstract}

Kata Kunci: Sistem Temu Kembali Citra, Local tri-directional pattern, Peregangan Kontras, Histogram Equalization, Perhitungan Jarak Canberra.

\section{Latar Belakang}




\section{Pemanfaatan Histogram Equalization pada Local Tri Directional Pattern untuk Sistem Temu Kembali Citra}

Visi komputer dan temu kembali citra (image retrieval), khususnya content based image retrieval (CBIR) telah menjadi issue yang paling banyak dikembangkan dan diteliti oleh para pakar pattern recognition. Telah banyak teknik image retrieval yang telah dikembangkan dalam beberapa tahun ini. Kunci utama pada CBIR adalah proses ekstraksi dari fitur-fitur seperti warna, tekstur, bentuk dan hubungan spasial (Smeulders, 2000). Sebelumnya, beberapa peneliti mengusulkan metode image retrieval berdasarkan tekstur pada citra berskala keabuan seperti gray-level co-occurrence matrix (GLCM), tekstur Tamura dan tekstur Wavelet (Sebastian, 2012).

Kemudian, metode ekstraksi fitur yang handal yaitu Local Binary Pattern (Ojala, 1996). Metode tersebut menggunakan intensitas lokal dari setiap piksel untuk mengekstrak vektor fitur. LBP menggunakan perbandingan piksel pusat dan piksel batas dengan threshold untuk pola biner. Saat ini telah banyak peneliti yang mengusulkan metode untuk mengembangkan LBP dan meningkatkan performa LBP. Namun, sebagian besar metode local pattern yang diusulkan menggunakan piksel ketetanggaan untuk mendapatkan informasi, namun hanya sedikit yang berdasarkan arah (direction).

Kemudian diusulkan metode local pattern berdasarkan arah yaitu local tri-directional pattern (LtriDP) (Verma, 2016). LBP menghasilkan pola lokal berdasarkan piksel pusat dan sekitarnya. Sedangkan pada LtriDP, hubungan piksel pusat dan sekitarnya dapat memanfaatkan informasi direksional citra. Hubungan timbal balik piksel tetangga ditiga arah yang paling signifikan dicari dalam metode ini. Pola magnitude juga dicari menggunakan piksel-piksel tiga arah. Kedua histogram yang dihasilkan kemudian digabung untuk menjadi vektor fitur. Namun, metode ini belum mampu memberikan performa yang baik dalam mengekstrak fitur untuk temu kembali citra. Salah satu alasan yang membuat performa temu kembali citra tidak baik adalah pengaruh pencahayaan (Starovoitov, 2003). Pencahayaan dapat menyebabkan variasi besar antar citra. Hal ini juga ditegaskan oleh (Delac, 2003) perbedaan pencahayaan pada tiap citra akan menjadi masalah dalam temu kembali citra.

Preprocessing citra memainkan peran penting dalam sistem temu kembali citra. Sebuah metode yang efektif untuk menangani berbagai kondisi cahaya pada dataset citra yang besar diusulkan yaitu Histogram equalization (HE). HE merupakan metode yang efektif untuk menangani berbagai kondisi cahaya pada dataset citra yang besar. HE merupakan metode fungsional dalam peregangan derajat keabuan dan memperluas kontras citra. Hal ini akan membuat variasi level keabuan dari citra asli dapat terkendali. Sehingga, dapat meningkatkan kualitas citra secara efektif (Gonzalez, 2008).

Penelitian ini mengusulkan metode HE untuk menangani kondisi cahaya beragam pada dataset citra yang digunakan dalam image retrieval pada metode LtriDP. Dengan dilakukannya perluasan kontras pada citra, diharapkan performa LtriDP dalam image retrieval meningkat.

\section{Dataset dan Metode}

\subsection{Dataset}

Dataset adalah sekumpulan data yang akan diolah oleh sistem untuk mendapatkan hasil output yang sudah ditentukan sistem. Pada metode yang diusulkan ini, data masukan yang dipakai adalah citra wajah dari tiga dataset berbeda yaitu ORL, YALE, dan BERN. Gambar 1, 2, dan 3 merupakan contoh citra dataset ORL, YALE, dan BERN.
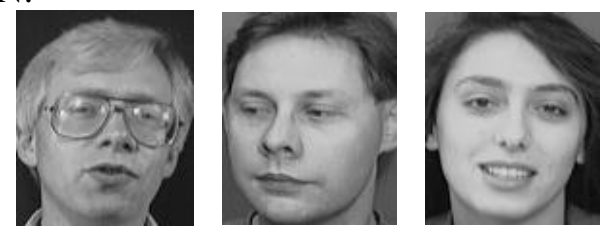

Gambar 1: Contoh citra dataset ORL

Sumber: http://cam-orl.co.uk/facedatabase.html/(2001) 


\section{Pemanfaatan Histogram Equalization pada Local Tri Directional Pattern untuk Sistem Temu Kembali Citra}

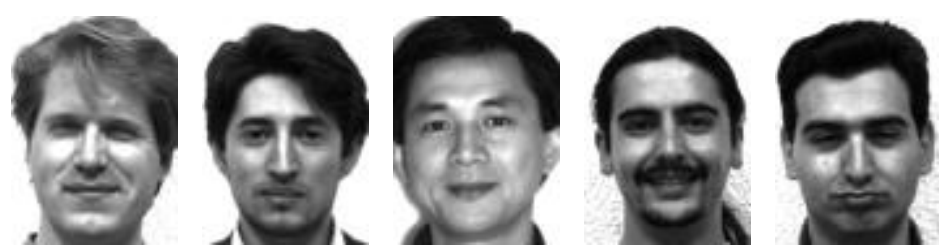

Gambar 2: Contoh citra dataset YALE

Sumber: https://vismod.media.mit.edu/vismod/classes/mas622-00/datasets/(1997)

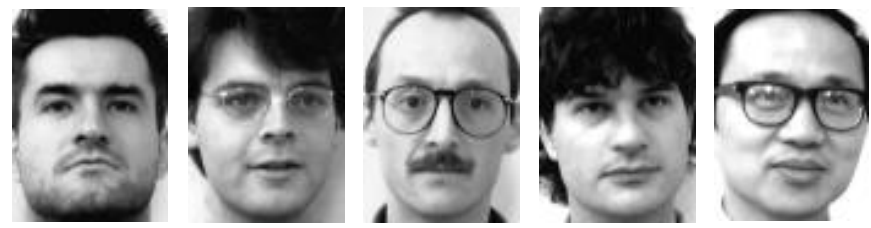

Gambar 3: Contoh citra dataset BERN

Sumber: http://www.iam.unibe.ch/fki/databases/iam-faces-database (2008)

\subsection{Metode}

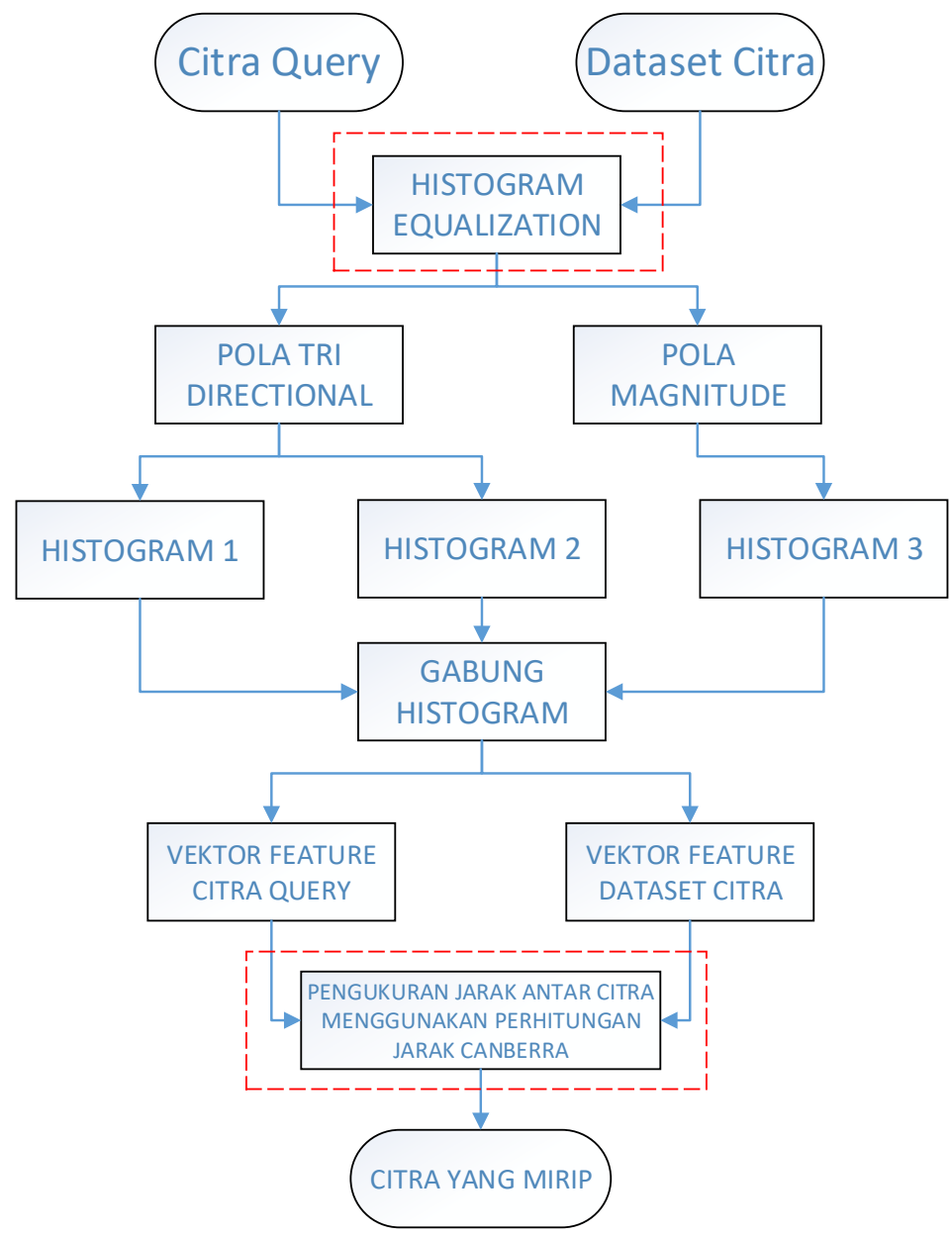

Gambar 4: Bagan alur metode penelitian

Gambar 4 merupakan bagan alur dari metode yang diusulkan. Pada penelitian ini, kami mengusulkan metode preprocessing sebelum melakukan ekstraksi fitur tri-directional pattern. Metode preprocessing yang kami usulkan adalah Histogram Equalization (HE). Citra query dan citra dataset akan terlebih dahulu melalui tahap preprocessing dengan HE. Setelah itu, citra yang telah melalui tahap preprocessing diekstrak fiturnya dicari pola tri-directional dan pola magnitude. Pola tri-directional akan menghasilkan dua histogram, sedangkan pola magnitude menghasilkan satu histogram. Ketiga histogram tersebut kemudian disatukan atau dilakukan joint histogram. Histogram yang telah disatukan merupakan vektor 


\section{Pemanfaatan Histogram Equalization pada Local Tri Directional Pattern untuk Sistem Temu Kembali Citra}

fitur. Vektor fitur tersebut akan dihitung ranking-nya menggunakan pengukuran jarak Canberra. Setelah itu akan didapatkan citra yang mirip dengan citra query.

\subsubsection{Histogram Equalization}

Histogram merupakan probabilitas statistik distribusi setiap level keabuan dalam citra digital. Histogram Equalization (HE) salah satu teknik yang sering digunakan untuk melakukan peningkatan kontras pada citra (Kim, 2008). Konsep dasar dari HE adalah dengan melakukan peregangan pada histogram, sehingga jarak piksel menjadi lebih besar.

Kontras didefinisikan sebagai perbedaan dalam pencahayaan atau warna yang membuat objek dalam suatu citra dapat dibedakan. Histogram memberikan informasi untuk tingkat kontras dan intensitas keseluruhan distribusi dari suatu citra. Misalkan citra input $f(x, y)$ terdiri dari level keabuan diskrit dalam kisaran $[0, L-1]$ maka fungsi transformasi $C\left(r_{k}\right)$ dapat didefinisikan sebagai Persamaan berikut: (Frank, 2010)

$$
S_{k}=T\left(r_{k}\right)=(L-1) \sum_{j=0}^{k} p_{r}\left(r_{j}\right)=\frac{L-1}{M N} \sum_{j=0}^{k} n_{j} \quad k=0,1,2, \ldots, \mathrm{L}-1
$$

Untuk persamaan transformasi HE pada citra digital, variabel $M \mathrm{x} N$ menunjukkan total jumlah piksel, $L$ jumlah level keabuan, dan $p_{r}\left(r_{j}\right)$ merupakan jumlah piksel dalam citra masukan dengan intensitas nilai $r_{j}$. Rentang nilai input dan output level keabuan berada di rentang nilai $0,1,2, \ldots, \mathrm{L}-1$. Kemudian, transformasi $\mathrm{HE}$ memetakan input nilai $r_{k}$ (di mana $\mathrm{k}=0,1,2, \ldots, \mathrm{L}-1$ ) hingga nilai output $S_{k}$. Maka, intensitas citra dapat didistribusikan pada histogram secara optimal. Sehingga, daerah kontras lokal yang lebih rendah dapat berubah menjadi kontras yang lebih tinggi tanpa mempengaruhi kontras global. Metode ini juga berguna untuk membedakan citra background dan foreground yang keduanya gelap atau keduanya terang.

\subsubsection{Local Tri Directional Pattern}

Local tri-directional pattern merupakan kepanjangan dari LtriDP. LtriDP mempertimbangkan hubungan berdasarkan arah yang berbeda. Setiap piksel pusat memiliki beberapa piksel tetangga dalam radius tertentu. Tetangga terdekat terdiri dari 8 piksel disekitar piksel pusat. Selanjutnya, ada 16 piksel dalam radius berikutnya dan seterusnya. Piksel tetangga terdekat yang kurang jumlahnya dan memberikan informasi lebih yang terkait karena mereka terdekat ke pusat piksel. Oleh karena itu, penelitian ini mempertimbangkan 8 tetangga piksel untuk penciptaan pola. Setiap piksel tetangga pada satu waktu dipertimbangkan dan dibandingkan dengan pusat piksel dan juga dengan dua piksel tetangga yang paling berdekatan. Kedua tetangga piksel ini adalah tetangga piksel vertikal atau horisontal karena mereka yang paling dekat berdasarkan ketetanggan piksel. Pembentukan pola ditunjukkan dalam Gambar 5.

Menentukan piksel pusat $I_{C}$ dan 8 piksel tetangga $I_{1}, I_{2}, \ldots$, dan $I_{8}$. Pertama, menghitung perbedaan antara setiap piksel tetangga dengan dua piksel yang paling berdekatan dan perbedaan masing-masing tetangga piksel dengan pusat piksel .

$$
\begin{array}{lcll}
D_{1}=I_{i}-I_{i-1}, & D_{2}=I_{i}-I_{i+1}, & D_{3}=I_{i}-I_{C} & \forall i=2,3, . .7 \\
D_{1}=I_{i}-I_{8}, \quad D_{2}=I_{i}-I_{i+1}, & D_{3}=I_{i}-I_{c} & \text { for } i=1 \\
D_{1}=I_{i}-I_{i-1}, \quad D_{2}=I_{i}-I_{1}, & D_{3}=I_{i}-I_{c} & \text { for } i=8 \\
f\left(D_{1}, D_{2}, D_{3}\right)=\left\{\#\left(D_{k}<0\right)\right\} \bmod 3 & \forall k=1,2,3 &
\end{array}
$$

Untuk $\#\left(D_{k}<0\right)$ menunjukkan jumlah total dari $D_{k}$ yang memiliki nilai kurang dari 0 , untuk $k=1,2,3$. $\#\left(D_{k}<0\right)$ memberikan nilai mulai dari 0 sampai 3 dan dalam mencarai nilai masing-masing pola, akan dihitung $\bmod 3$ dari nilai $\#\left(D_{k}<0\right)$, misalnya, nilai dari $D_{k}<0, k=1,2,3$ dan di mod 3, maka \# $\left(D_{k}<0\right)$ 


\section{Pemanfaatan Histogram Equalization pada Local Tri Directional Pattern untuk Sistem Temu Kembali Citra}

mod 3 adalah 0 . Dengan cara ini, \#( $\left.D_{k}<0\right)$ mod 3 adalah nilai 0,1 dan 2. Penjelasan lebih tentang perhitungan nilai pola, terdapat pada contoh di Gambar 5. Untuk setiap tetangga piksel " $i=1,2, \ldots, 8$ ", nilai pola $f_{i}\left(D_{1}, D_{2}, D_{3}\right)$ dihitung dengan menggunakan persamaan (6), dan pola tri-directional telah diperoleh. (Verma, 2016)

(a)

\begin{tabular}{|l|l|l|}
\hline $\mathrm{I}_{6}$ & $\mathrm{I}_{7}$ & $\mathrm{I}_{8}$ \\
\hline $\mathrm{I}_{5}$ & $\mathrm{I}_{\mathrm{C}}$ & $\mathrm{I}_{1}$ \\
\hline $\mathrm{I}_{4}$ & $\mathrm{I}_{3}$ & $\mathrm{I}_{2}$ \\
\hline
\end{tabular}

(f)

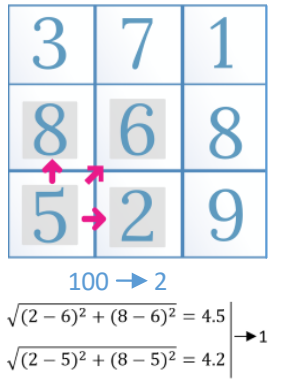

(b)

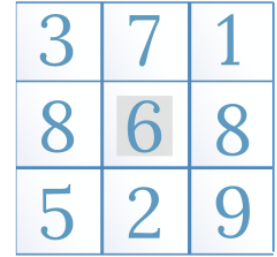

(g)

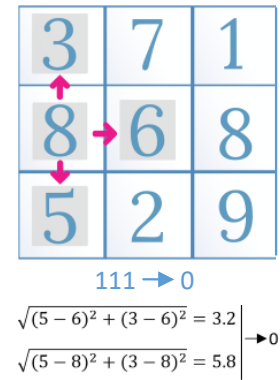

(c)

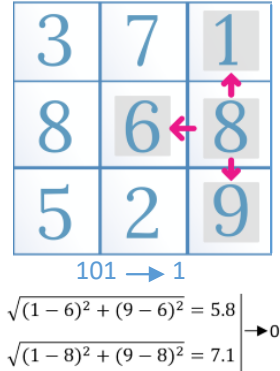

(h)

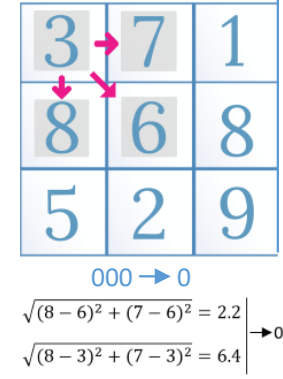

(d)

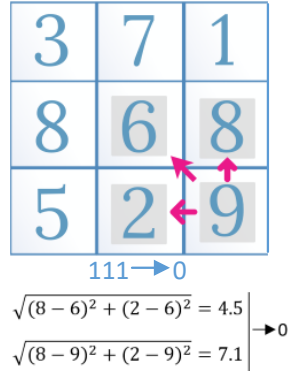

(i)

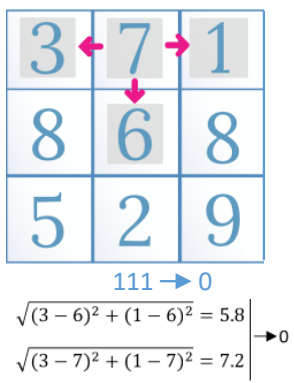

(e)

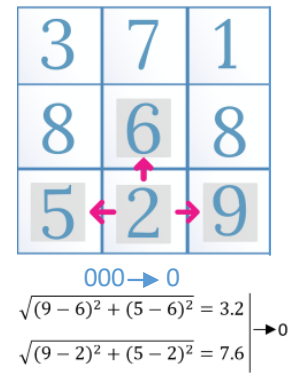

(j)

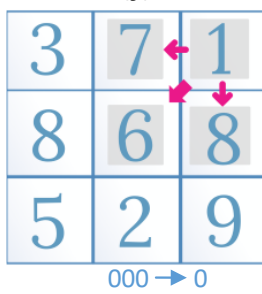

$\sqrt{(7-6)^{2}+(8-6)^{2}}=2.2 \mid \rightarrow 0$

Pola Tri Directional $=10020000$

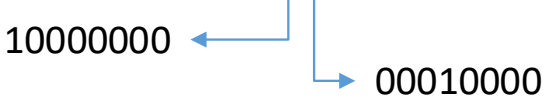

Pola Magnitude $=00010000$

Gambar 5: Contoh penerapan sampel window. (a) Notasi piksel pusat dan ketetanggaan (b) Contoh window (c)-(j) Perhitungan pola Local tri-directional pattern dan pola magnitude.

\subsubsection{Magnitude Pattern}

Pola tri-directional mengekstrak sebagian besar informasi lokal, tetapi menunjukkan bahwa pola magnitude juga membantu dalam penciptaan vektor fitur yang lebih informatif. Kami juga telah menerapkan pola magnitude didasarkan pada pusat piksel, tetangga piksel dan dua piksel yang paling berdekatan (Verma, 2016). Pola magnitudenya dibuat sebagai berikut:

$$
\begin{aligned}
& M_{1}=\sqrt{\left(I_{i-1}-I_{C}\right)^{2}+\left(I_{i+1}-I_{C}\right)^{2}} \\
& M_{2}=\sqrt{\left(I_{i-1}-I_{i}\right)^{2}+\left(I_{i+1}-I_{i}\right)^{2}}, \quad \forall i=2,3, . .7 \\
& M_{1}=\sqrt{\left(I_{8}-I_{C}\right)^{2}+\left(I_{i+1}-I_{C}\right)^{2}} \\
& M_{2}=\sqrt{\left(I_{8}-I_{i}\right)^{2}+\left(I_{i+1}-I_{i}\right)^{2}}, \quad \text { for } i=1 \\
& M_{1}=\sqrt{\left(I_{i-1}-I_{C}\right)^{2}+\left(I_{1}-I_{C}\right)^{2}} \\
& M_{2}=\sqrt{\left(I_{i-1}-I_{i}\right)^{2}+\left(I_{1}-I_{i}\right)^{2}}, \quad \text { for } i=8
\end{aligned}
$$

Nilai-nilai dari $M_{1}$ dan $M_{2}$ dihitung untuk setiap piksel tetangga dan berdasarkan dengan nilai-nilai dibawah ini, nilai pola magnitude yang diperuntukkan untuk setiap piksel tetangga.

$$
\operatorname{Mag}_{i}\left(M_{1}, M_{2}\right)=\left\{\begin{array}{cc}
1, & M_{1} \geq M_{2} \\
0, & \text { else }
\end{array}\right.
$$




\section{Pemanfaatan Histogram Equalization pada Local Tri Directional Pattern untuk Sistem Temu Kembali Citra}

$$
\begin{gathered}
\operatorname{LTriD} P_{\text {mag }}\left(I_{C}\right)=\left\{\operatorname{Mag}_{1}, \operatorname{Mag}_{2}, \ldots, \operatorname{Mag}_{8}\right\} \\
\left.\operatorname{LTriDP}\left(I_{C}\right)\right|_{\text {mag }}=\sum_{l=0}^{7} 2^{l} x \operatorname{LTriD} P_{\text {mag }}\left(I_{C}\right)
\end{gathered}
$$

Dimana $I_{C}$ dan $I_{i}$ adalah pusat piksel dan intensitas piksel tetangga. Kemudian, histogram dari pola magnitude dibuat berdasarkan persamaan (13)

$$
\left.\operatorname{His}(L)\right|_{\text {Pattern }}=\sum_{c=1}^{m} \sum_{b=1}^{n} S_{2}(\operatorname{Pattern}(a, b), L) ;
$$

Pattern adalah singkatan dari Local Binary Pattern, dan ukuran dari citra adalah $m \times n$.

\subsubsection{Joint Histogram}

Tahap selanjutnya adalah proses joint histogram pola directional dan histogram magnitude. Tiga histogram disatukan, dan tahap joint histogram dibuat berdasarkan:

$$
\text { Hist }=\left[\left.H i s\right|_{L T r i D P_{1}},\left.H i s\right|_{L T r i D P_{2}},\left.H i s\right|_{L T r i D P_{m a g}}\right]
$$

Contoh perhitungan pola ditunjukkan pada Gambar 5 melalui window $(a)$ - (j). Pada window (a), pusat piksel $I_{C}$ dan tetangga piksel $I_{1}, I_{2}, \ldots, I_{8}$ akan ditampilkan. Pusat piksel yang ditandai sebagai warna merah di window $(b)$ - $(j)$. Pada jendela berikutnya $(c), I_{l}$ lingkungan piksel pertama ditandai sebagai warna biru, dan dua piksel yang paling berdekatan ditandai sebagai warna kuning. Pertama, metode ini membandingkan piksel biru dengan piksel kuning dan piksel merah dan ' 0 ' atau '1' nilai yang ditentukan untuk semua tiga perbandingan. Misalnya, di jendela $(c) I_{1}$ dibandingkan dengan $I_{8}, I_{2}$ dan $I_{C}$. Sejak $I_{1}>I_{8}, I_{1}<I_{2}$ dan $I_{1}>I_{C}$, pola untuk $I_{1}$ adalah 101. Sekarang, menurut persamaan. (6) nilai pola untuk $I_{1}$ adalah 1 . Dengan cara yang sama, untuk window berikutnya $(d)-(j)$ nilai pola yang diperoleh untuk piksel tetangga lainnya.

Akhirnya, pola tri-directional local untuk pusat piksel diperoleh dengan penggabungan semua nilai pola tetangga piksel. Untuk pola magnitudenya, besarnya pusat piksel dan tetangga piksel diperoleh dan dibandingkan. Dalam contoh yang disajikan, "6" adalah pusat piksel dan $I_{l}$ adalah " 8 ". Pada jendela (c), besarnya pusat pixel "6" adalah 5.8 dan besarnya " 8 " adalah 7.1 sehubungan dengan " 1 " dan " 9 ". Sejak, besarnya pusat piksel kurang dari tetangga piksel, ditetapkan "0" nilai pola di sini. Akibatnya, pola magnitude dihitung untuk piksel tetangga berikutnya dapat dilihat pada window $(d)$ - $(j)$, dan pola magnitude semua piksel tetangga digabung menjadi satu pola dan yang pola magnitude untuk pusat piksel.

\subsubsection{Perhitungan Kedekatan menggunakan Jarak Canberra}

Perhitungan kedekatan merupakan hal yang paling berpengaruh pada sistem temu kembali citra. Dengan perhitungan kedekatan ini akan menghasilkan jarak antara feature factor dan ketidakmiripan antara satu citra dengan citra yang lain menggunakan sebuah matrik jarak. Pada penelitian ini, kami menggunakan Perhitungan Kedekatan Jarak Canberra yang didefinisikan sebagai berikut:

$$
j\left(v_{1}, v_{2}\right) \sum_{k=1}^{N} \frac{\left|v_{1}(k)-v_{2}(k)\right|}{\left|v_{1}(k)\right|+\left|v_{1}(k)\right|}
$$

dalam hal ini, $N$ menyatakan panjang vektor, kemudian $v_{1}$ dan $v_{2}$ adalah dua vektor yang jaraknya akan dihitung.

\section{Hasil dan Diskusi}

Pada penelitian ini, dilakukan pengujian terhadap metode yang diusulkan menggunakan tiga dataset yang berbeda. Kemudian, dilakukan juga evaluasi kinerja terhadap metode yang diusulkan dengan menggunakan perhitungan recall. Recall adalah persentase dari semua citra yang relevan di dataset pencarian query citra. 


\section{Pemanfaatan Histogram Equalization pada Local Tri Directional Pattern untuk Sistem Temu Kembali Citra}

Recall $=\frac{\text { Number of relevant images retrieved }}{\text { Number of relevant images in database }}$

3.1 Dataset $O R L$

Dataset ORL terdiri atas 400 citra dengan 40 objek yang berbeda. Setiap objek mempunyai 10 citra dengan ekspresi wajah yang berbeda-beda. Ukuran citra pada dataset ini adalah 92x112. Dari 10 citra yang ada akan diambil 1 citra sebagai testing dan 9 citra lainnya akan digunakan sebagai database untuk masing - masing objek.

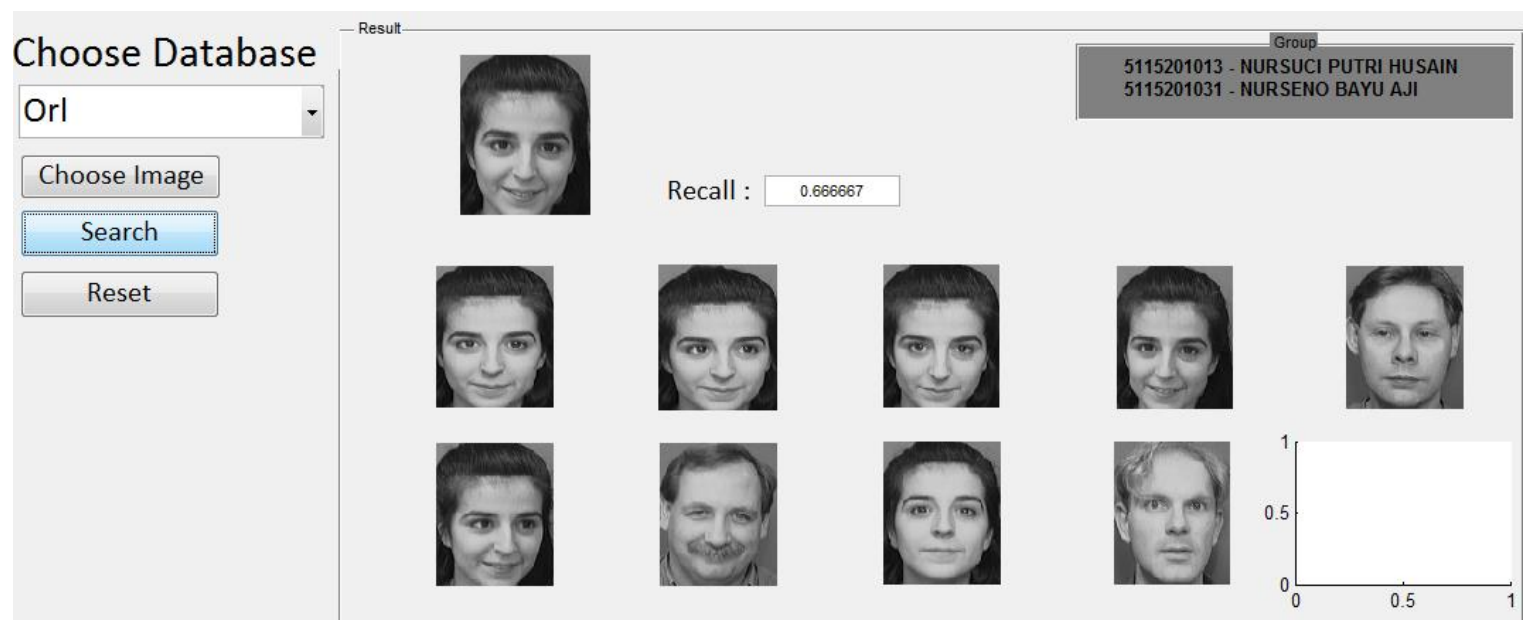

Gambar 6: Contoh pencarian citra dataset ORL menggunakan metode yang diusulkan

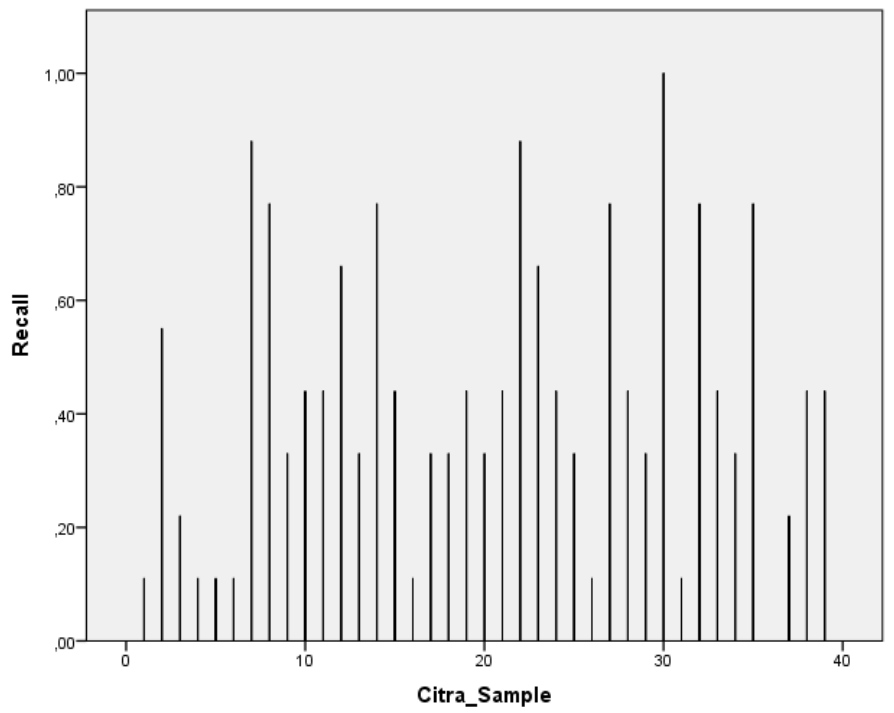

Gambar 7: Grafik Nilai Recall tiap jenis citra pada dataset ORL

Gambar 6 adalah salah satu contoh pencarian citra query menggunakan metode yang diusulkan terhadap dataset ORL. Dapat dilihat hasil pencarian citra yang memiliki similarity yang dekat. Pada Gambar 6 terdapat citra yang diujikan (citra yang paling atas) dan 9 citra dibawahnya merupakan citra kembalian dari sistem. Citra kembalian tersebut akan dilihat presentase citra yang sesuai dengan citra diujikan, pada Gambar 6 terdapat 6 dari 6 citra yang sesuai dengan citra yang diujikan sehingga nilai recall didapatkan 0,7. Kemudian pada Gambar 7. Terlihat nilai recall pada tiap jenis citra pada dataset ORL, dan didapatkan nilai rata-rata recall pada dataset ORL yaitu 0,422.

\subsection{Dataset YALE}

Dataset YALE terdiri atas 165 citra dengan 15 objek yang berbeda. Setiap objek mempunyai 11 citra dengan ekspresi wajah yang berbeda-beda. Ukuran citra pada dataset ini adalah $64 \times 88$. Sama skenario pada data ORL, akan diambil 1 citra yang diujikan dan sisanya akan berada dalam database, karena 


\section{Pemanfaatan Histogram Equalization pada Local Tri Directional Pattern untuk Sistem Temu Kembali Citra}

jumlah citra untuk masing - masing objek yaitu 11. Sehingga, untuk data YALE yang akan dimasukkan ke database pengujian sebanyak 10 citra.

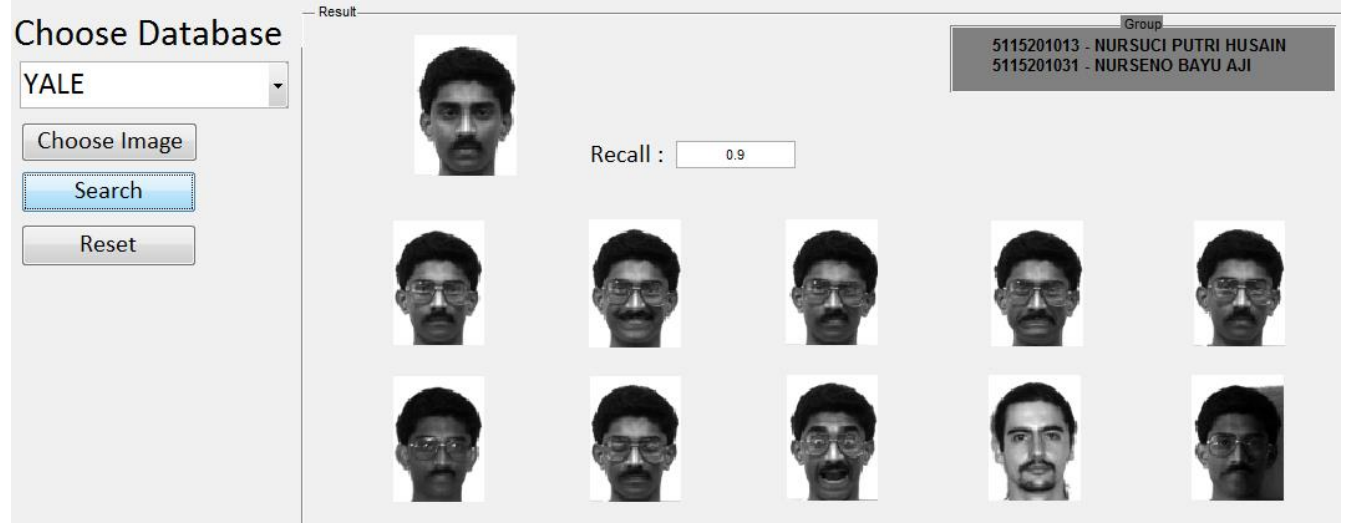

Gambar 8: Contoh pencarian citra dataset YALE menggunakan metode yang diusulkan

Gambar 8 adalah salah satu contoh pencarian citra query menggunakan metode yang diusulkan dengan pengujian pada dataset YALE. Pada Gambar 8 sistem berhasil mengembalikan citra yang sesuai dengan citra uji sebanyak 9 citra dari 10 citra sehingga recall yang didapatkan 0,9. Kemudian pada Gambar 9. terlihat nilai recall pada tiap jenis citra pada dataset YALE, dan didapatkan nilai Rata-rata recall pada dataset YALE adalah 0,63.

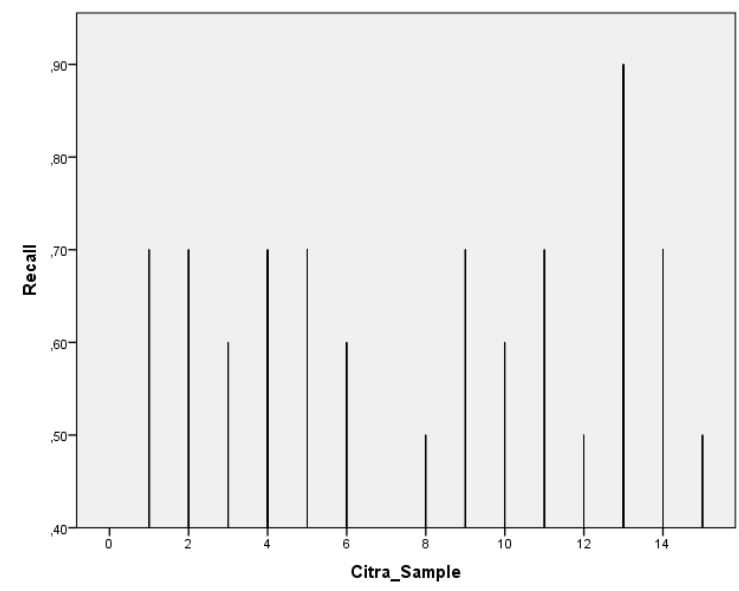

Gambar 9: Grafik nilai recall tiap citra pada dataset YALE

\subsection{Dataset BERN}

Dataset BERN terdiri atas 280 citra dengan 28 objek yang berbeda. Setiap objek mempunyai 10 citra dengan ekspresi wajah yang berbeda-beda. Ukuran citra pada dataset ini adalah $64 \times 88$. Untuk dataset Bern memiliki skenario yang sama dengan data ORL, yaitu 1 citra uji dan 9 citra database.

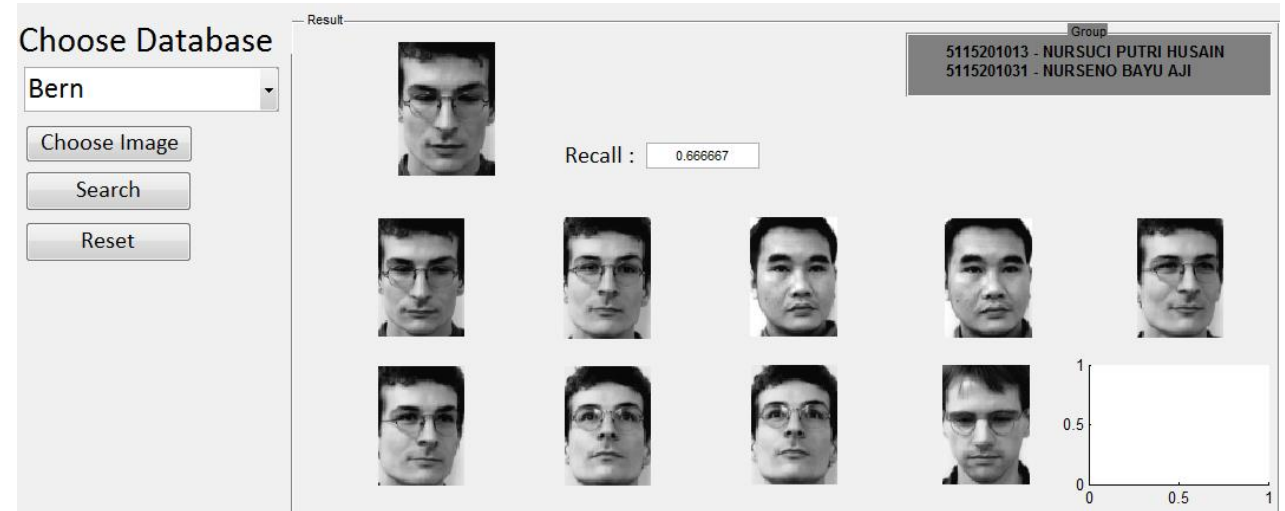

Gambar 10: Contoh pencarian citra dataset BERN menggunakan metode yang diusulkan 


\section{Pemanfaatan Histogram Equalization pada Local Tri Directional Pattern untuk Sistem Temu Kembali Citra}

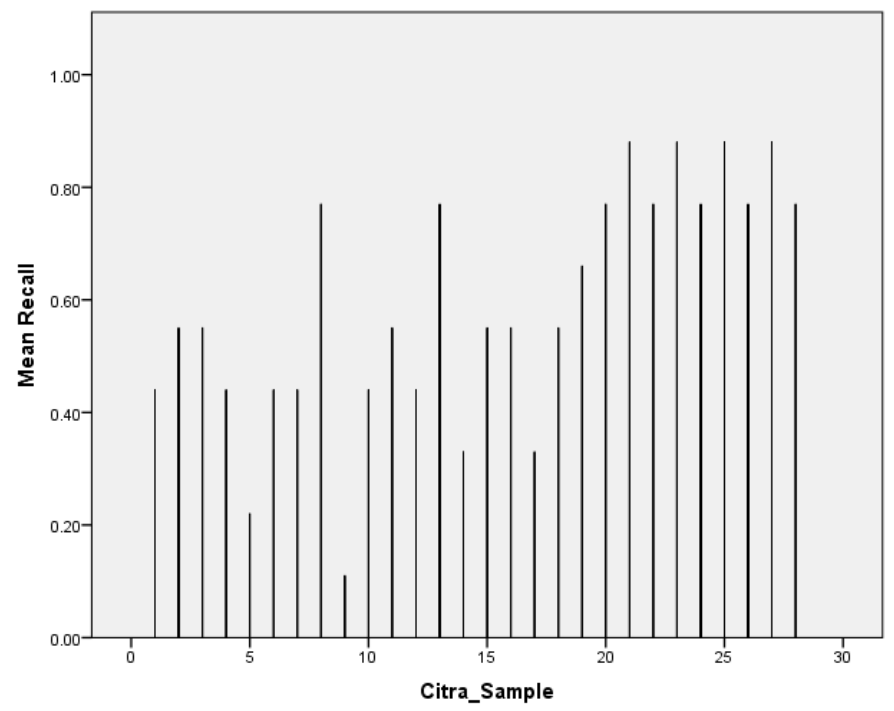

Gambar 11: Nilai recall tiap jenis citra pada dataset BERN

Gambar 10 adalah salah satu contoh pencarian citra query menggunakan metode yang diusulkan terhadap dataset BERN . Dapat dilihat hasil pencarian citra yang memiliki similarity yang dekat. Kemudian pada Gambar 11, terlihat nilai recall pada tiap jenis citra pada dataset YALE, dan didapatkan nilai rata-rata recall pada dataset BERN adalah 0,5893.

Local pattern menggunakan intensitas lokal piksel untuk meraih informasi dan menciptakan pola sesuai dengan informasi. LBP membandingkan lingkungan piksel dan pusat piksel dan menetapkan pola ke piksel pusat. Dalam penelitian yang diusulkan, hubungan tambahan antara piksel lokal telah diamati. Seiring dengan hubungan antara pusat piksel tetangga, hubungan timbal balik piksel tetangga yang berdekatan diperoleh, dan informasi lokal berdasarkan tiga arah piksel diperiksa. Metode ini memberikan informasi lebih lanjut dibandingkan dengan LBP dan pola lokal lainnya, seperti menghitung informasi pusat-tetangga piksel bersama dengan informasi piksel tetangga bersama. tetangga terdekat memberikan sebagian besar informasi. Oleh karena itu, pola dihitung menggunakan sebagian piksel tetangga yang berdekatan untuk setiap nilai pola. Juga, pola magnitude diperkenalkan yang menyediakan informasi mengenai ukuran intensitas untuk setiap piksel. Kedua LTriDP dan pola magnitude, memberikan informasi yang berbeda dan memberikan deskripsi fitur yang lebih baik.

Dari hasil nilai rata-rata recall yang didapatkan pada metode yang diusulkan, masih terdapat beberapa citra yang tidak bisa ditemukan berdasarkan citra query yang dimasukkan. Hal ini dapat terjadi, karena sebaran intensitas piksel pada semua citra hampir sama. Sehingga, pada saat pencarian query ditemukan beberapa citra yang wajahnya tidak sama dengan wajah pada citra query.

\section{Kesimpulan}

Penelitian ini mengusulkan metode histogram equalization untuk menangani kondisi cahaya beragam pada dataset citra yang digunakan dalam image retrieval pada metode LtriDP. Dari hasil uji coba yang telah dilakukan terhadap tiga dataset citra yaitu ORL, YALE, dan BERN pada system image retrieval yang kami usulkan, dapat diambil kesimpulan bahwa adanya tahap preprocessing histogram equalization memberikan nilai akurasi yang lebih tinggi. Adapun nilai rata-rata recall yang didapat untuk masing-masing dataset adalah 0,589 untuk dataset BERN, kemudian 0,422 untuk dataset ORL, dan 0,63 untuk dataset YALE. Pada penelitian selanjutnya, perlu dilakukan modifikasi metode LtriDP agar akurasi lebih meningkat.

\section{Daftar Pustaka}

AT\&T Laboratories Cambridge, database wajah ORL, tersedia secara online: http://camorl.co.uk/facedatabase.html, 2001. 


\section{Pemanfaatan Histogram Equalization pada Local Tri Directional Pattern untuk Sistem Temu Kembali Citra}

Delac, K., Grgic, M., Kos, T., (2006). 'Sub-Image Homomorphic Filtering Technique for Improving Facial Identification under Difficult Illumination Conditions', International Conference on Systems, Signals and Image Processing, Budapest, Hungary.

Gonzalez, R.C., Woods, R. E, (2008). 'Digital Image Processing 3rd edition', Prentice Hall, Upper Saddle River.

Kim, T. dan Paik, J. 2008. 'Adaptive Contras Enhancement Using Gain-Controllable Clipped Histogram Equalization’, IEEE Trans. Counsumer Electr., Vol: 54, 1803-1810.

Ojala, T., Pietikäinen, M., Harwood, D. (1996) ,'A comparative study of texture measures with classification based on featured distributions', Pattern Recognition, Vol: 29, Issue: 1, 51-59.

Sebastian V, B., Unnikrishnan, A., Balakrishnan, K. (2012), 'Grey level co-occurrence matrix: generalization and some new features', International Journal of Computer Science, Engineering and Information Technology, Vol: 2, No: 2, 151-157.

Shih Frank Y., (2010), 'Image Processing and Pattern Recognition Fundamental and Techniques', IEEE Press and A Jhon Wiley and Sons, Inc, Publication.

Smeulders, A. W. M., Worring, M., Santini, S., Gupta, A., Jain, R. (2000), 'Content-based image retrieval at the end of the early years', IEEE Transactions of Pattern analysis and machine intelligence, Vol: 22 , Issue: 12, 1349-1380.

Starovoitov, V. V., Samal, D.I., Briliuk, D.V. (2003), 'Image Enhancement for Face Recognition', International Conference on Iconics, St.Petersburg, Russia.

The Face Database of the University of Bern, database wajah BERN, tersedia secara online: http://www.iam.unibe.ch/fki/databases/iam-faces-database, 2008.

Verma, M., \& Raman, B. (2016). 'Local tri-directional patterns : A new texture feature descriptor for image retrieval', Digital Signal Processing, Vol: 51, 62-72.

Yale Face Database, tersedia secara online: https:/vismod.media.mit.edu/vismod/classes/mas622-00/datasets/, 1997. 